\title{
Which Factors Affect Landless Peasants' Intention for Entrepreneurship? A Case Study in the South of the Yangtze River Delta, China
}

\author{
Lu Han ${ }^{1}$, Haijun Bao ${ }^{2, *}$ and Yi Peng ${ }^{2}$ \\ 1 Institute of Land and Urban-Rural Development, Zhejiang University of Finance \& Economics, \\ Hangzhou 310018, China; sara_hh@126.com \\ 2 School of Public Administration, Zhejiang University of Finance \& Economics, Hangzhou 310018, China; \\ pengyihz@gmail.com \\ * Correspondence: baohaijun@zufe.edu.cn
}

Received: 5 May 2017; Accepted: 27 June 2017; Published: 3 July 2017

\begin{abstract}
Landless peasants have been a great concern for both the government and academics in China. Entrepreneurship is promoted as one of the most important approaches to achieving civilization and urbanization. However, few studies have systematically examined the influencing factors of landless peasants' entrepreneurial intention (EI). This research gap presents barriers for making effective policies to promote entrepreneurship among landless peasants. This study aims to examine the critical factors influencing the EI of landless peasants and their interrelationships. The critical factors of landless peasants' EI are identified using logistic regression analysis. The logical and structural relationships among critical factors are mined by interpretative structural modeling. A chain of factors with an interrelated and clear hierarchy is built to clarify the explanatory structure of landless peasants' EI. The results show that the EI of landless peasants is significantly influenced by five factors: gender, achievement motivation, innovation orientation, land expropriation scenario, and entrepreneurial experience. Entrepreneurial experience is a direct surface factor; innovation orientation is an indirect intermediate layer factor; and gender, achievement motivation, and land expropriation scenario are deeply rooted factors. The results provide a good reference for formulating effective entrepreneurship policies to address landless peasants' employment and sustainable livelihoods.
\end{abstract}

Keywords: landless peasants; entrepreneurial intention (EI); land expropriation scenario; interpretive structural modeling (ISM); China

\section{Introduction}

China's government has expropriated a large amount of agricultural land to meet the demands of infrastructure and property development in the urbanization of China [1-5]. Based on the amount of expropriated land and changes in the per capita land area, the number of Chinese landless peasants is estimated to reach more than 50 million in 2008. Approximately 100 million Chinese landless peasants are expected in the next decade according to China's current urbanization level and economic growth rate. Considerable amounts of land should be expropriated for transportation, water conservancy, energy, and other infrastructure facilities, and for the implementation of many significant strategies, e.g., "the Belt and Road Initiative".

Many landless peasants face significant challenges in employment, which is restricted by the economy, society, institutions, the culture background, capital, and other factors [6]. China has long been confronted with an accelerated stage of rural labor employment $[7,8]$. A large number of rural laborers have migrated to cities for non-agricultural employment. According to the National Bureau 
of Statistics of China, the new working-age population in cities reached 13.12 million in 2015, and the unemployment rate was $4.05 \%$. In addition, the total number of rural-urban migrants working in Chinese urban areas reached 169 million in 2015, representing $27.98 \%$ of the total rural population and $45.58 \%$ of the rural working-age population. On average, nearly one-third of working-aged residents left their rural hometowns to work in cities. Therefore, the employment pressure of rural labors is increasing. The difficulties in employment result from the drawbacks of the Chinese urban-rural dual structure, land expropriation and resettlement policies, and other institutional designs and arrangements. The skyrocketing urbanization of China under external forces, the regional industrial structure, and economic development strategies have failed to achieve synergized development with sustainable livelihood security for landless peasants [9]. Technology, talent, capital, and other innovative elements have converged to create new waves of "micro-entrepreneurship" under the rapid urbanization in China. Encouraging entrepreneurship is "an important measure" for the sustainable livelihood of these people [10]. As former President Hu Jintao said in the "the Eighteenth National Congress of the Communist Party of China" in 2012, "guiding employment is necessary to change the employment ideas, encourage multi-channel and multi-form employment, and promote entrepreneurship to create jobs."

Entrepreneurship is an important measure to promote landless peasants' employment $[10,11]$. The development strategy of "entrepreneurship for creating jobs" was further developed on the basis of "doing everything possible to expand employment" ("Report to the 16th National Congress of the Communist Party of China"). The Report "the 17th National Congress of the Communist Party of China" by Hu Jintao emphasized "placing priority over encouraging entrepreneurship and supporting entrepreneurship in employment work, and clearly creating jobs through the promotion of entrepreneurship" [12]. Similar local policies have followed. Chinese landless peasants are mainly employed by private small and medium enterprises, small and micro enterprises, and individual economies. The private sector contributes more than $90 \%$ of the increment in society-wide employment [13]. Therefore, new initiatives and ideas related to encouraging and promoting the self-employment of landless peasants serve as practical solutions to ensure the future subsistence and development of landless peasants.

However, few studies have systematically examined the influencing factors of landless peasants' entrepreneurial intention (EI). Thus, how to effectively promote entrepreneurship among landless peasants remains unclear. The present study aims to identify the influencing factors of landless peasants' EI and their interrelationships to mitigate such insufficiencies. Section 2 critically reviews relevant studies on the entrepreneurship of landless peasants. A solid theoretical and practical background is introduced in this section. Section 3 introduces the research method and data source of this study. Logistic regression is used to identify the critical factors influencing landless peasants' EI based on the theoretical analysis. Interpretative structural modeling (ISM) is employed to characterize the interrelationships among critical influencing factors. Section 4 presents the findings of this study. Section 5 provides an in-depth discussion, and concludes the paper with recommendations for future studies.

\section{Literature Review}

Landless peasants refer to peasants who actively or passively lose all or part of their land for urban construction because of rapid urbanization across China. The entrepreneurship of landless peasants refers to landless peasants who are self-employed and run their own businesses rather than being employed by others after losing their farmland. The Chinese Entrepreneurship Monitor Report mentioned that partly employed college students, laid-off workers, and landless peasants account for $90 \%$ of the total number of entrepreneurs in China. These groups mainly run businesses by "following suit" and tend to be "satisfied with small wealth". The EI of landless peasants means the intention to start entrepreneurship, which is the best predictor of the entrepreneurial behavior of landless peasants [14]. The entrepreneurship experience of landless peasants refers to the past experience of 
landless peasants to offer independent production and service items and to achieve market-oriented employment. This experience includes the establishment of standard companies, individual operations, and a large number of non-formal labor organizations that are unregistered as businesses. Landless peasants in this process provide valuable products or services and obtain remuneration. According to previous research, past entrepreneurship experience has an important influence on EI. Some scholars explore the relationship between past entrepreneurship experience and EI [15-17]. Schildt et al. [18] reveal that the past entrepreneurship experience of entrepreneurs has a positive influence on EI. Some studies have found that the previous experience, including previous entrepreneurial experience, industry experience, management experience, specific R \& D work experience and other functional work experience, affects EI [13,19-21]. Other studies have studied the impact of human capital factors such as education, training experience, and skills on entrepreneurship [22,23].

Entrepreneurship is an important development strategy for individuals to solve problems related to employment discrimination and unemployment [24,25]. Australia, Canada, and the United Kingdom have encouraged unemployed people to pursue self-employment and solve the persistent problem of unemployment. They have endorsed entrepreneurial activities of youth groups, lowered barriers encountered by women's groups in entrepreneurship, raised the ratio of business owners in minority groups, and promoted the entrepreneurial activities of indigenous inhabitants. Various measures have been taken in many countries to encourage and support disadvantaged groups for entrepreneurship. These measures enable them to remove their unfavorable status and embark on a development path. The United States has enacted a number of decrees on vocational training and education since the 1960s [26]. Vocational training improves the quality of labor and gives impetus to the employment of laborers, alleviating the problem of unemployment [27]. Moreover, the United States currently extends entrepreneurship training to disadvantaged and unemployed groups and develops a comprehensive entrepreneurship support system to boost the development of disadvantaged groups [28].

Entrepreneurship is proposed as one of the most effective ways to settle landless peasants [10,29]. Considerable international research has focused on the entrepreneurship of peasants and immigrants [30]. Pyysiäinen et al. [31] and De Haan [32] argued that the entrepreneurial task of traditional agriculture is different from diversified entrepreneurship because the latter greatly requires market relations, professional skills, and the ability to obtain resources. The skills are directly connected with networks, relationships, and social resources. The fundamental restrictor of the entrepreneurship of peasants is the rural entrepreneurial environment itself. Different regional goals and policy frameworks should be developed in different entrepreneurship environments [33]. The entrepreneurship of immigrants can help them obtain employment and overcome poverty, and it is also an important factor that contributes to social and economic development in many Western countries [34]. Western scholars have attached importance to the first generation of entrepreneurial activities of voluntary immigrants [35], whose demands for policies are specific. For example, policies for social, human, financial, and cultural capital are valuable for the entrepreneurship of immigrants [36]. China has conducted some pilot studies on landless peasants' entrepreneurship.

The impact factors of EI have been investigated in several studies. Landless peasants live in low social strata, and their EIs are hampered by the urban-rural dual system [3]. In the system, many factors play a role, such as subjectivity factors (e.g., capacity and psychological factors) [3,37], institution factors (e.g., discrimination, unfair treatment, and social security) $[3,38]$, and the entrepreneurial environment (e.g., venture capital, the level of economic development, and relevant governmental policies) $[39,40]$.

Various research methods have been applied to discuss landless peasants' EI. Lian et al. [41] used regression analysis to analyze the factors that influence the EI of Chinese peasants. Lin and Si [3] analyzed the impact of self-efficacy and the institutional environment on EI by using a regression analysis based on 298 samples of Chinese farmers. Yu, Zhou, Wang and Xi [39] discussed some important factors and institutional effects on entrepreneurship in China's rural entrepreneurship (such as regulatory, normative and cognitive components) based on 91 stories of rural entrepreneurs reported 
by CCTV. However, the current studies mainly remain at the theoretical stage with few empirical investigations. Other empirical studies have focused on determining the significant influencing factors without in-depth insights into the correlation and the hierarchy among these factors. Some studies have analyzed the relationship among various factors quantitatively, but most are under the premise of theoretical assumptions and lack the quantitative analysis for model building of the logical hierarchy of factors. The ISM method overcomes the limitations of the aforementioned methods. It effectively avoids subjectivity and considers the interaction among various influencing factors to fully and accurately confirm the hierarchical relationship between the primary and secondary structures of various influencing factors. Therefore, the purpose of this study is to investigate the interrelationships of the influencing factors of landless peasants' EI through ISM.

\section{Research Method}

\subsection{Research Logic and Relevant Methods}

Logistic-ISM is adopted to investigate the influencing factors of landless peasants' EI and their interrelationships. This model combines the logistic regression model and the ISM analysis method. First, the statistical analysis software SPSS18.0 is used to estimate the significant influencing factors of the EI of landless peasants using a logistic model. $S_{i}(i=1,2, \ldots, k)$ is used to indicate $k$ influencing factors of the EI of landless peasants. Second, the correlation among the various influencing factors and the multi-level staircase structure are analyzed according to ISM analysis. Finally, a connecting link between both methods is established by integrating $\mathrm{k}$ influencing factors into the results of the logistic model and $k$ component factors in the ISM analysis system, enabling the interactive applications of logistic-ISM. The specific model is constructed as follows.

\subsubsection{Logistic Model}

Logistic regression analysis is applicable when the dependent factor is a dichotomous factor, which is an ideal model to analyze individual decision-making behavior. The EI of landless peasants in this study (i.e., the subjective probability of the choice of landless peasants to implement EI) includes "willing" and "unwilling" cases. Every land-lost farmer makes the best choice based on rational comprehensive measurement for various influencing factors; this choice is a typical binary decision. Therefore, the binary logistic regression model is applied in this study [42]. The logistic model can be specified as follows:

$$
S_{L}=\frac{\operatorname{Exp}\left(\beta_{0}+\beta_{1} \chi_{1}+\beta_{2} \chi_{2}+\cdots+\beta_{m} \chi_{m}\right)}{1+\operatorname{Exp}\left(\beta_{0}+\beta_{1} \chi_{1}+\beta_{2} \chi_{2}+\cdots+\beta_{m} \chi_{m}\right)}
$$

where $S_{L}$ is the dependent factor (the EI of landless peasants) with two discrete values of 0 and $1 . X_{i}$ is the considered influencing factors specified in Section 3.2. $\beta_{0}$ is a constant term unrelated to $X_{i}$, which indicates the natural logarithm of the odds ratio of the willing and unwilling EIs of landless peasants when the independent factor is $0 . \beta_{1}, \beta_{2}, \ldots, \beta_{m}$ are partial regression coefficients to indicate the contribution of various factors $X_{i}$ to $P$. This study used the logistic model to analyze the key influencing factors of landless peasants' EI. The model is the premise of ISM for analyzing the relationship of the influencing factors.

\subsubsection{ISM}

ISM is an effective tool used for dealing with complex situations [43-45]. Warfield [46] proposed the ISM approach, and it was used to make a complex system into a visualized hierarchical structure for researching structural problems in complex social and economic systems. The core idea of ISM is to extract the constituent elements of problems; apply directed graph, matrix, and other tools; process elements, their mutual relations, and other information; and ultimately configure a well-structured system [47]. ISM analysis effectively gains insights into the structure and influencing factors of complex social and economic systems. This method has been widely used for primary (key) influencing factor 
analysis and recognition in the fields of corporate core competitiveness, the green supply chain implementation effect, industrial cluster risk, and the formation of engineering quality accidents in recent years. The aim of using ISM in this study is to find the essential relationship among primary (key) factors identified through Logistics regression, reveal the inherent law of a system structure and extract useful information. First, in the system of EI of landless peasants, the influencing factors of EI are interrelated and independent. According to the relationship of the influencing factors, a directed graph was formed and transformed into adjacency matrix. Second, the reachable matrix is obtained by the Boolean operation algorithm of the adjacency matrix. Third, the multi-level hierarchical structure of the influencing factors was obtained among complex system elements. The detailed process of ISM model is explained as follows.

(1) An adjacency matrix is established among various factors. The adjacency matrix represents the logical relationship among the factors. $k$ key influencing factors of landless peasant' entrepreneurship are obtained through Logistics regression, which are denoted as $S_{i}(i=1,2, \ldots, k)$. The logical relationship among the $k$ key influencing factors indicates whether two factors mutually influence each other and serve as the premise to each other or maintain other relations. The component elements of the adjacency matrix $R$ among factors are defined by

$$
r_{i j}=\left\{\begin{array}{cc}
1, & S_{i} \text { is related to } S_{j} \\
0, & S_{i} \text { is not related to } S_{j}
\end{array} \quad i=0,1, \cdots, k ; j=0,1, \cdots, k\right.
$$

(2) A reachable matrix among factors is determined. The reachable matrix refers to the extent of the reachability of the factors in a matrix after a certain path length. It reflects all the direct and indirect relationships among the influencing factors of the EI of landless peasants. A reachable matrix $M$ can be obtained according to the following equation:

$$
M=(R+I)^{\lambda+1}=(R+I)^{\lambda} \neq(R+I)^{\lambda-1} \neq \cdots \neq(R+I)^{2} \neq(R+I)
$$

where I refers to a unit matrix, $2 \leq \lambda \leq k$. The Boolean operation algorithm is used in the exponentiation operation of the matrix.

(3) The layer of influencing factors is determined. First, the highest layer factors are determined, and the reachable matrix is divided into a reachable set $P\left(S_{i}\right)$ and an antecedent set $Q\left(S_{i}\right)$, as shown in Equation (4). $P\left(S_{i}\right)$ represents a collection of all of the factors that can be reached from the factor $S_{i}$ of the reachable matrix and $Q\left(S_{i}\right)$ represents a collection of all of the factors that can be reached in the $S_{i}$.

$$
P\left(S_{i}\right)=\left\{S_{i} \mid m_{i j}=1\right\}, Q\left(S_{i}\right)=\left\{S_{i} \mid m_{j i}=1\right\}
$$

In Equation (4), $m_{i j}$ and $m_{j i}$ are the factors of the reachable matrix $M$. The factor satisfying the requirements of Equation (5) is the highest level.

$$
L_{I}=\left\{S_{i} \mid P\left(S_{i}\right) \cap Q\left(S_{i}\right)=P\left(S_{i}\right) ; i=0,1, \cdots, k\right\}
$$

Second, the factors of other layers are identified. The corresponding rows and columns of factors in $L_{1}$ are deleted from the original reachable matrix $M$. Thus, matrix $M^{\prime}$ is obtained. The operations for $M^{\prime}$ are repeated according to Equations (4) and (5). The factors in the second layer $L_{2}$ and other layers are generated by analog.

(4) The hierarchical structure of the influencing factors is determined. A directed edge is used to connect the factors between adjacent layers and those on the same layer. The hierarchical structure of the influencing factors of the EI of landless peasants is obtained by connecting all factors in the identified layers. 


\subsection{Factors and Measurement}

The preliminary influencing factors of the EI of landless peasants are identified through a literature review to conduct logistic regression. These factors fall within the scopes of EI, individual characteristics, desire perception, feasible perception, land expropriation scenario, and entrepreneurial experience.

(1) The EI factor is a type of psychological state that leads to the attention, energy and behavior of individual entrepreneurs [14]. Krueger [48] believes that EI represents the degree of commitment of entrepreneurs to start a business. The higher the commitment is, the stronger the EI is. Potential entrepreneurs with a strong EI can be engaged only in entrepreneurial action. Currently, research on the influencing factors of EI mainly involves the individual and the environment [17]. The influencing factors of EI in this study include individual characteristics, desire perception, feasible perception, land expropriation scenario, and entrepreneurial experience.

(2) Individual characteristic factors can be expressed as the personality traits and abilities of landless peasants. They mainly emphasize the human, social, physical, and other capital conditions of landless peasants with possible influences on entrepreneurship. The individual characteristic factors in this study include age, gender, education level, and household income. Older peasants show a high risk-averse trend and are unwilling to accept new ideas and technologies. A high educational level implies a strong ability to accept new things and easily confront challenges. Family income is directly related to funding for EI.

(3) Desire perception factors refer to the attractiveness of the prospects of conducting an entrepreneurial activity to landless peasants. These factors reflect whether entrepreneurship satisfies the needs of landless peasants; that is, the value brought by entrepreneurship. Desire perception factors include characteristic factors, such as achievement motivation (AM) and innovation orientation (IO). These individual characteristics indicate whether landless peasants have the potential to become entrepreneurs. This potential is mirrored in every aspect of individual life.

(4) Feasible perception factors refer to the extent that landless peasants believe in their ability to conduct an entrepreneurial activity, and these factors reflect landless peasants' own judgment about their ability, that is, the feasibility of entrepreneurship. This idea is understood as the perceptual judgment of landless peasants (potential entrepreneurs) about their own entrepreneurial knowledge, skills, and experiences. A strong feasible perception implies a high possibility of entrepreneurship. Feasible perception factors include the perception of social capital (SC) providers, the perception of markets and opportunities (MO), and other resource factors. These resources, which can be individually perceived by landless peasants (potential entrepreneurs), are criteria for the feasibility of the entrepreneurship of landless peasants.

(5) Land expropriation scenario factors include the land location (LL), the amount of compensation (AC), the resettlement mode (SM), and entrepreneurship policy (EP). The land location factor refers to the distance from expropriated LL to the main urban area (i.e., villages in city, urban fringes, and remote rural areas) and the development type of the expropriated land (i.e., villages in scenic spots, resorts, and economic and technological development zones). The compensation amount factor is based on the expropriated LL, which is significantly related to different types of land expropriation projects. The difference in the level of regional economic development influences the compensation amount. The resettlement mode factor refers to whether landless peasants enjoy in-situ or housing resettlement. Peasants can lease their houses to obtain rental income. The entrepreneurship policy factor refers to relevant policy for the entrepreneurship of landless peasants. Such policy includes credit financing, platform construction, entrepreneurship training, and related services. Whether entrepreneurship guidance is given, entrepreneurship training is conducted, and other support policies are launched that influence the choices and judgments of landless peasants for EI. 
(6) Entrepreneurial experience factors are whether the landless peasants have past entrepreneurship experience. Entrepreneurial experience (EE) has an important impact on EI, as demonstrated in existing studies.

A total of 6 aspects and 14 factors are selected. The specific factors and their statistical characteristics are shown in Table 1.

Table 1. Factor description and statistical features.

\begin{tabular}{|c|c|c|}
\hline \multicolumn{2}{|c|}{ Factor Name } & \multirow{2}{*}{$\begin{array}{c}\text { Factor Description } \\
\text { Willing }=1 \text {; unwilling }=0\end{array}$} \\
\hline $\begin{array}{l}\text { Entrepreneurial } \\
\text { intention (EI) }\end{array}$ & $\begin{array}{l}\text { Entrepreneurial } \\
\text { intention }(\mathrm{EI})\end{array}$ & \\
\hline \multirow{4}{*}{$\begin{array}{l}\text { Individual } \\
\text { characteristics }\end{array}$} & Gender & Male $=1 ;$ Female $=0$ \\
\hline & Age & $\begin{array}{l}\leq 30 \text { years old }=1 ; 31 \sim 40 \text { years old }=2 ; 41 \sim 50 \text { years old }=3 ; \\
51 \sim 60 \text { years old }=4\end{array}$ \\
\hline & Education & $\begin{array}{l}\text { Primary and below }=1 \text {; junior high school }=2 \text {; the high } \\
\text { school/technical secondary school }=3 \text {; college and above }=4\end{array}$ \\
\hline & Income & $\begin{array}{l}\text { Annual household income of less than } 20,000=1 \text {; annual } \\
\text { household income of } 20,000 \text { to } 30,000=2 \text {; annual household } \\
\text { income of } 30,000 \text { to } 50,000=3 \text {; household annual income of } \\
50,000 \text { to } 100,000=4 ; \text { household income of more than } 100,000=5\end{array}$ \\
\hline \multirow{2}{*}{ Desire perception } & $\begin{array}{c}\text { Achievement } \\
\text { Motivation (AM) }\end{array}$ & $\begin{array}{l}\text { Strongly disagree }=1 ; \text { comparatively disagree }=2 ; \text { neutral }=3 ; \\
\text { Comparatively agree }=4 ; \text { strongly agree }=5\end{array}$ \\
\hline & $\begin{array}{l}\text { Innovation-oriented } \\
\text { (IO) }\end{array}$ & $\begin{array}{l}\text { Strongly disagree }=1 ; \text { comparatively disagree }=2 ; \text { neutral }=3 ; \\
\text { Comparatively agree }=4 ; \text { strongly agree }=5\end{array}$ \\
\hline \multirow{2}{*}{ Feasible perception } & Social Capital (SC) & $\begin{array}{l}\text { Strongly disagree }=1 ; \text { comparatively disagree }=2 ; \text { neutral }=3 ; \\
\text { Comparatively agree }=4 ; \text { strongly agree }=5\end{array}$ \\
\hline & $\begin{array}{l}\text { Market opportunities } \\
\text { (MO) }\end{array}$ & $\begin{array}{l}\text { Strongly disagree }=1 ; \text { comparatively disagree }=2 ; \text { neutral }=3 ; \\
\text { Comparatively agree }=4 ; \text { strongly agree }=5\end{array}$ \\
\hline \multirow{4}{*}{$\begin{array}{l}\text { Land expropriation } \\
\text { scenario }\end{array}$} & Land Location (LL) & $\begin{array}{l}\text { Strongly disagree }=1 ; \text { comparatively disagree }=2 ; \text { neutral }=3 ; \\
\text { Comparatively agree }=4 ; \text { strongly agree }=5\end{array}$ \\
\hline & $\begin{array}{l}\text { Resettlement Mode } \\
\qquad(\mathrm{SM})\end{array}$ & $\begin{array}{l}\text { Strongly disagree }=1 ; \text { comparatively disagree }=2 ; \text { neutral }=3 ; \\
\text { Comparatively agree }=4 ; \text { strongly agree }=5\end{array}$ \\
\hline & $\begin{array}{c}\text { Amount of } \\
\text { Compensation }(\mathrm{AC})\end{array}$ & $\begin{array}{l}\text { Strongly disagree }=1 ; \text { comparatively disagree }=2 ; \text { neutral }=3 ; \\
\text { Comparatively agree }=4 ; \text { strongly agree }=5\end{array}$ \\
\hline & $\begin{array}{l}\text { Entrepreneurship } \\
\text { policy (EP) }\end{array}$ & $\begin{array}{l}\text { Strongly disagree }=1 ; \text { comparatively disagree }=2 ; \text { neutral }=3 ; \\
\text { Comparatively agree }=4 ; \text { strongly agree }=5\end{array}$ \\
\hline $\begin{array}{l}\text { Entrepreneurial } \\
\text { experience }\end{array}$ & $\begin{array}{l}\text { Entrepreneurial } \\
\text { experience (EE) }\end{array}$ & $\begin{array}{l}\text { Strongly disagree }=1 ; \text { comparatively disagree }=2 ; \text { neutral }=3 ; \\
\text { Comparatively agree }=4 ; \text { strongly agree }=5\end{array}$ \\
\hline
\end{tabular}

\subsection{Study Area}

The two cities, Hangzhou and Ningbo, in the south of the Yangtze River Delta, are selected as the study area because of their representativeness of EI of landless peasants of cities with similar conditions in the Yangtze River Delta. The representation is mainly embodied in two aspects. First, the case cities are located in the south of the Yangtze River Delta, which is growing into one of the most influential world-class metropolitan areas. It is one of the most economically developed and densely populated areas in China. Moreover, the case cities play an irreplaceable role in the economic and social development of the Yangtze River Delta. Rapid industrialization and urbanization have brought about a large number of landless peasants in recent years. For instance, in the process of the G20 Summit Forum and the 19th Asian Games, the local government of Hangzhou plans to conduct land acquisition and reconstruction involving 178 urban villages and 8816 households from 2016-2020. A large amount of land acquisition has brought more large-scale landless peasants. Therefore, the two cities can provide a good observation of landless peasants during rapid urbanization in China. Second, people in the case cities are forced to sustain life by developing a private economy (entrepreneurship) because of the lack of farmland. The private economy is prosperous in the case cities, which has provided various entrepreneurial industry alternatives. For instance, Alibaba's business model has driven the excellent entrepreneurial climate and entrepreneurial environment of micro-enterprises in 
Hangzhou. It makes Hangzhou become the most popular city of micro-entrepreneurship in China. Ningbo has a long history of entrepreneurship (such as "Ningbo Bang"). The local government of Ningbo has provided a large number of support policies for entrepreneurship, such as the new subsidy policy for entrepreneurship in 2017. Therefore, the case cities are suitable for studying EI.

The case cities are located in the south of the Yangtze River Delta. Its representative cities are Hangzhou and Ningbo, which are close to Shanghai. The land area of the case cities is 45,400 square kilometers, which accounts for $44 \%$ of the area of Zhejiang Province. People in the case cities are forced to sustain life by developing a private economy (entrepreneurship) because of the lack of farmland. According to Zhejiang Province Bureau of Statistics, as of the end of 2014, approximately $24,519,900$ permanent residents were in the urban agglomeration areas, and $43.99 \%$ of them lived in urban areas. Its gross domestic product (GDP) was 2922.79 billion RMB as of 2015, accounting for $67.88 \%$ of the GDP of Zhejiang Province. The industrial and urbanization development of Hangzhou and Ningbo are the most prominent in the urban agglomeration. The GDPs of the two areas as of 2015 were 10,053.58 billion RMB and 801.15 billion RMB. The per capita annual disposable income of rural residents is 25,719 RMB in Hangzhou and 26,469 RMB in Ningbo. The per capita annual disposable income of urban residents is 48,316 RMB in Hangzhou and 47,852 RMB in Ningbo. The urban-rural gap of these areas is still large. The registered unemployment rates of urban residents in Hangzhou and Ningbo are only $8.50 \%$ and $12.38 \%$, which imply sufficient employment.

A large area of rural land has been expropriated during the rapid industrialization and urbanization process. The government has taken various policies and approaches to settle landless peasants. The resettlement policy in the south of the Yangtze River Delta has transitioned from government-led policy (such as production resettlement, welfare resettlement) to market-dominant policy (such as currency settlement, land usufruct returning, life guarantee, and developmental resettlement) $[10,29,49]$. Hangzhou has established a "one-stop" service center for entrepreneurship, and it provides counseling, employment assistance, training and education, and micro-credit. Incentive policies for entrepreneurship have been established, such as free housing for three years, opening subsidies, and monthly social security subsidies [50]. Entrepreneurship policy for landless peasants has been developed to promote the self-employment of landless peasants in the urban agglomeration. At the end of 2015, the Ningbo Municipal Government invested 39.431 million RMB for training landless peasants, and the number of beneficiaries was 111,000. Moreover, the Pension Insurance System in Ningbo is the best in China. The pension construction of landless peasants has been fully realized. The field investigation reveals that landless peasants are more engaged in low-end industry to maintain their livelihood. The involved businesses include bed and breakfast (B \& B), catering, fruit and vegetable wholesale, car washes, taxis, logistics, and architecture. This background information of the entrepreneurial industry of landless peasants is useful for comprehending the analytical results in the following sections.

\subsection{Data Source and Survey Design}

Questionnaires were designed on a five-point Likert scale, and the respondents were asked to indicate their attitudes toward the propositions. Points 1 to 5 refer to "strongly disagree", "disagree", "unsure", "agree", and "strongly agree", respectively. A pretest was conducted for 20 landless peasants in Jiubao Town, Hangzhou, before the formal questionnaires were distributed. Their comments on the meanings and grammatical expression of questions were requested. The questionnaires were then modified according to feedback. The entire questionnaire consisted of 26 measuring items. The formal survey questionnaires were distributed to landless peasants in Hangzhou and Ningbo in July 2014. The targeted respondents in the survey were landless peasants. Random sampling was used to determine landless peasants living in the urban villages and communities in the suburban areas of Hangzhou and Ningbo. The survey used Chinese because it is the primary language in the study areas. Due attention was given to minimize information loss during translation. In the field survey, a total of 400 questionnaires were distributed, 350 questionnaires were collected, and 307 of them were 
valid. The proportion of the surveyed male and female landless peasants was almost balanced (i.e., men: $49.2 \%$; women: $50.8 \%$ ). The entrepreneurial age distribution of landless peasants was different from those in other entrepreneurship groups, who are mainly 30-50 years old (i.e., 31-40 years old: $34.9 \%$; $41-50$ years old: $32.9 \%$ ). Most of the landless peasants received senior high school or secondary school education $(38.8 \%)$, followed by junior high school $(35.5 \%)$. Most of the landless peasants had an annual household income of 50,000-100,000 RMB (36.8\%), followed by an annual household income of 30,000-50,000 RMB (30.6\%). It can be seen that landless peasants of Hangzhou and Ningbo have relatively high income in the process of urbanization. However, as consumption of two cities is relatively high, some landless peasants still live a poor life. Landless peasants have extremely strong EI in the two cities, but most of them present "subsistence-type" entrepreneurship so that entrepreneurial successful rate is not satisfying. The characteristics of the sample survey in this study are consistent with previous studies [29] and can reflect the whole population of landless peasants in the two case cities. The following subsection presents the analysis and findings of the survey.

\section{Results}

\subsection{Logistic Regression Analysis of the EI of Landless Peasants}

This study conducts a logistic regression analysis of 307 data samples. First, all factors are considered. The estimation is conducted according to Equation (1), and the preliminary model estimation results are obtained. Second, the accompanying probability value is identified, and the screening method of the backward maximum likelihood is adopted. Insignificant factors are excluded until all factors reach a statistical significance level of $10 \%$, and the final model estimation results are obtained. The regression coefficients, statistics, and $p$-values of these factors are shown in Table 2 . Table 2 indicates that the equation passes the Hosmer-Lemeshow goodness-of-fit test. The statistical value of the -2 times the log-likelihood values of the final model is 102.1630, that of Cox and Snell $R^{2}$ is 0.6217 , and that of Nagelkerke $R^{2}$ is 0.8531 . Thus, the explained factor fluctuates at a range of over $80 \%$ and indicates a high goodness of fit of the model. The final model presents significant differences of 0.0000 , which is much less than 0.01 . The final regression results of the model imply that five factors enter into the final model: gender, AM, IO, LL, and EE. Therefore, the five factors are statistically significant for the EI of landless peasants.

Table 2. Logistic regression results of the EI factors.

\begin{tabular}{|c|c|c|c|c|c|c|}
\hline \multirow[b]{2}{*}{ Factor Name } & \multicolumn{3}{|c|}{ Initial Estimated Results } & \multicolumn{3}{|c|}{ Final Estimation Results } \\
\hline & $\begin{array}{c}\text { Regression } \\
\text { Coefficients (B) }\end{array}$ & $\begin{array}{l}\text { Statistics } \\
\text { (Wald) }\end{array}$ & $\begin{array}{l}p \text {-Value } \\
\text { (Sig.) }\end{array}$ & $\begin{array}{c}\text { Regression } \\
\text { Coefficients (B) }\end{array}$ & $\begin{array}{l}\text { Statistics } \\
\text { (Wald) }\end{array}$ & $\begin{array}{l}p \text {-Value } \\
\text { (Sig.) }\end{array}$ \\
\hline Gender & 0.8109 & 1.7933 & 0.1805 & $1.0800 *$ & 3.7095 & 0.0541 \\
\hline Age & 0.2292 & 0.4551 & 0.4999 & - & - & - \\
\hline Education & 0.3120 & 0.7124 & 0.3986 & - & - & - \\
\hline Income & 0.1902 & 0.4152 & 0.5193 & - & - & - \\
\hline $\mathrm{AM}$ & $0.8798^{* *}$ & 4.5720 & 0.0325 & $0.7183 * *$ & 4.1552 & 0.0415 \\
\hline IO & $-1.4844 * * *$ & 10.8853 & 0.0010 & $-1.4360^{* * *}$ & 12.3803 & 0.0004 \\
\hline MO & -0.4545 & 1.3115 & 0.2521 & - & - & - \\
\hline SC & 0.0362 & 0.0067 & 0.9347 & - & - & - \\
\hline $\mathrm{AC}$ & -0.4973 & 0.9270 & 0.3356 & - & - & - \\
\hline SM & -0.0630 & 0.0229 & 0.8797 & - & - & - \\
\hline LL & $0.9270 * *$ & 6.2050 & 0.0127 & $0.8508^{* *}$ & 6.4786 & 0.0109 \\
\hline EP & 0.1091 & 0.1077 & 0.7428 & - & - & - \\
\hline $\mathrm{EE}$ & $6.6277^{* * *}$ & 42.6248 & 0.0000 & $6.0569 * * *$ & 50.7148 & 0.0000 \\
\hline Constant & -21.8836 & 32.0297 & 0.0000 & -20.5137 & 40.0701 & 0.0000 \\
\hline $\begin{array}{c}-2 \text { times the } \\
\text { log-likelihood values }\end{array}$ & \multicolumn{3}{|c|}{97.3910} & \multicolumn{3}{|c|}{102.1630} \\
\hline Cox \& Snell $R^{2}$ & \multicolumn{3}{|c|}{0.6275} & \multicolumn{3}{|c|}{0.6217} \\
\hline Nagelkerke $R^{2}$ & \multirow{2}{*}{\multicolumn{3}{|c|}{$\begin{array}{l}0.8611 \\
0.0000\end{array}$}} & \multirow{2}{*}{\multicolumn{3}{|c|}{0.8531}} \\
\hline Significance level & & & & & & \\
\hline
\end{tabular}




\subsection{Interpretive Structure of Influences of the EI of Landless Peasants}

According to the specific steps of ISM analysis, the first is to determine the system composition $S_{i}=\left(S_{1}, S_{2}, \cdots, S_{n}\right)$. In this paper, five variables, namely, gender, achievement motivation (AM), innovation orientation (IO), land location (LL), and entrepreneurial experience (EE), are respectively denoted by $S_{1}, S_{2}, S_{3}, S_{4}, S_{5}$. On the basis of a detailed investigation and advice from relevant experts, the logical relationships between the influencing factors of landless peasants' EI, with the two factors mutually influencing each other, serve as premises for each other or maintain other relationships. "V" indicates the row factors' influence on the column factors, and " $\mathrm{A}$ " indicates the column factors' influence on the row factors, as shown in Figure 1.

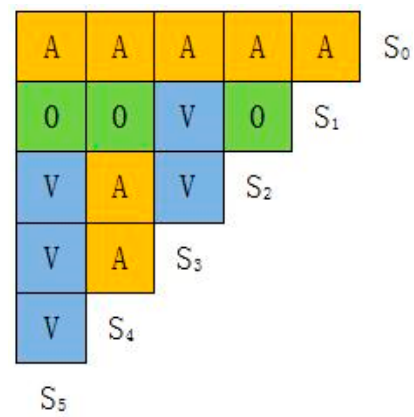

Figure 1. Logical relationship between factors.

The adjacency matrix $R$ of influencing factors is obtained according to Figure 1 and Equation (2), as shown in Equation (6).

$$
R=\begin{aligned}
& S_{0} \\
& S_{1} \\
& S_{2} \\
& S_{3} \\
& S_{4} \\
& S_{5}
\end{aligned}\left[\begin{array}{llllll}
0 & 0 & 0 & 0 & 0 & 0 \\
1 & 0 & 0 & 1 & 0 & 0 \\
1 & 0 & 0 & 1 & 0 & 1 \\
1 & 0 & 0 & 0 & 0 & 1 \\
1 & 0 & 0 & 1 & 0 & 1 \\
1 & 0 & 0 & 0 & 0 & 0
\end{array}\right]
$$

According to the calculation principles for the component elements of a reachable matrix, a reachable matrix $M$ of influencing factors is obtained from adjacency matrix $R$, as shown in Equation (7). Table 3 considers the transitivity rule according to the reachable matrix.

$$
M=\begin{aligned}
& S_{0} \\
& S_{1} \\
& S_{2} \\
& S_{3} \\
& S_{4} \\
& S_{5}
\end{aligned}\left[\begin{array}{llllll}
1 & 0 & 0 & 0 & 0 & 0 \\
1 & 1 & 0 & 1 & 0 & 1 \\
1 & 0 & 1 & 1 & 0 & 1 \\
1 & 0 & 0 & 1 & 0 & 1 \\
1 & 0 & 0 & 1 & 1 & 1 \\
1 & 0 & 0 & 0 & 0 & 1
\end{array}\right]
$$

Table 3. Reachability matrix $M$.

\begin{tabular}{ccccccccc}
\hline & & $\mathbf{1}$ & $\mathbf{2}$ & $\mathbf{3}$ & $\mathbf{4}$ & $\mathbf{5}$ & $\mathbf{6}$ & Driving Power \\
\hline EI & $S_{0}$ & 1 & 0 & 0 & 0 & 0 & 0 & 1 \\
Gender & $S_{1}$ & 1 & 1 & 0 & 1 & 0 & 1 & 4 \\
AM & $S_{2}$ & 1 & 0 & 1 & 1 & 0 & 1 & 4 \\
IO & $S_{3}$ & 1 & 0 & 0 & 1 & 0 & 1 & 3 \\
LL & $S_{4}$ & 1 & 0 & 0 & 1 & 1 & 1 & 4 \\
EE & $S_{5}$ & 1 & 0 & 0 & 0 & 0 & 1 & 2 \\
Dependence power & 6 & 1 & 1 & 4 & 1 & 5 & \\
\hline
\end{tabular}


Table 3 shows the factors' driving power and dependence power. The driving power is the total value of the rows of reachability matrix $M$, which is the factor that may have an effect. For example, the driving power of EI is 1, and the driving power of gender is 4 . The dependence power is the total value of the columns of reachability matrix $M$, which may have an effect on the factor. For example, the dependence power of $\mathrm{EI}$ is 6, and the driving power of gender is 1 .

For reachable matrix $M$, first, $L_{1}=\left\{S_{0}\right\}$ is obtained according to Equations (4) and (5). According to the method of determining the factors at other layers, $L_{2}=\left\{S_{5}\right\}, L_{3}=\left\{S_{3}\right\}$ and $L_{4}=\left\{S_{1}, S_{2}, S_{4}\right\}$ are obtained. According to $L_{1}, L_{2}, L_{3}$ and $L_{4}$, the sorted reachable matrix $B$ is obtained, as shown in Equation (8).

\begin{tabular}{|c|c|c|c|c|c|c|}
\hline & $S$ & $S_{5}$ & $S_{3}$ & $S_{1}$ & $S_{2}$ & $S_{4}$ \\
\hline$S_{0}$ & {$[1$} & 0 & 0 & 0 & 0 & 0 \\
\hline$S_{5}$ & 1 & 1 & 0 & 0 & 0 & 0 \\
\hline$S_{3}$ & 1 & 1 & 1 & 0 & 0 & 0 \\
\hline$S_{1}$ & 1 & 1 & 1 & 1 & 0 & 0 \\
\hline$S_{2}$ & 1 & 1 & 1 & 0 & 1 & 0 \\
\hline$S_{4}$ & 1 & 1 & 1 & 0 & 0 & 1 \\
\hline
\end{tabular}

According to Equation (6), $S_{0}$ is at Layer I, $S_{5}$ (EE) is at Layer II, $S_{3}(\mathrm{IO})$ is at Layer III, and $S_{1}$ (Gender), $S_{2}(A M), S_{4}(L L)$ is at Layer IV, which form an influencing factor chain with logical relationships. Then, using a directed edge to connect the factors between adjacent layers and at the same layer, this study obtains the hierarchical structure of influencing factors of landless peasants' EI, as shown in Figure 2.

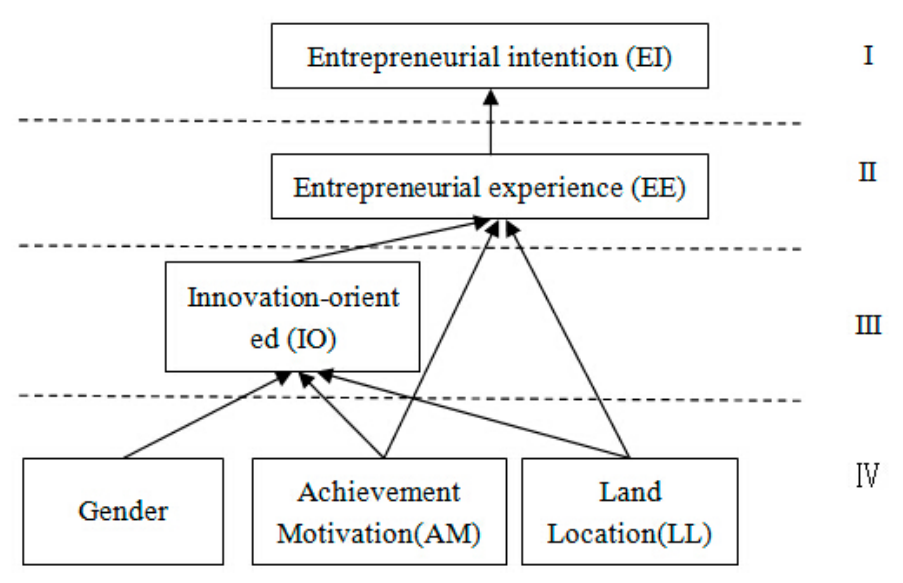

Figure 2. The ISM model for the influencing factors of EI of landless peasants.

According to the factors' driving power and dependence power, "Matrice d'Impacts croises-multipication applique an classment (MICMAC)" was used to evaluate the drive power and dependence power of factors [44,51]. Four sectors of the factors are separated [52] (Figure 3), which include an autonomous factor, dependent factor, linkage factor, and independent factor. Specifically, the autonomous factors are in sector I and have a weak driving power and weak dependence power. In this study, there is no autonomous factor. This distribution shows that all factors are relatively connected to the system. The dependent factors are in sector II and have weak driving power but strong dependence power. The EI, IO and EE factors fall into this sector. This distribution indicates that the EI, IO and EE factors have weak driving power but strong dependence power. The linkage factors are in sector III and have both strong driving power and dependence power. None of the factors are in this sector. The independent factors are in sector IV and have strong driving power but weak dependence power. The gender, AM, and LL factors fall into this sector. Thus, the research suggests that the factors in sector IV are the "key factors" [44]. 


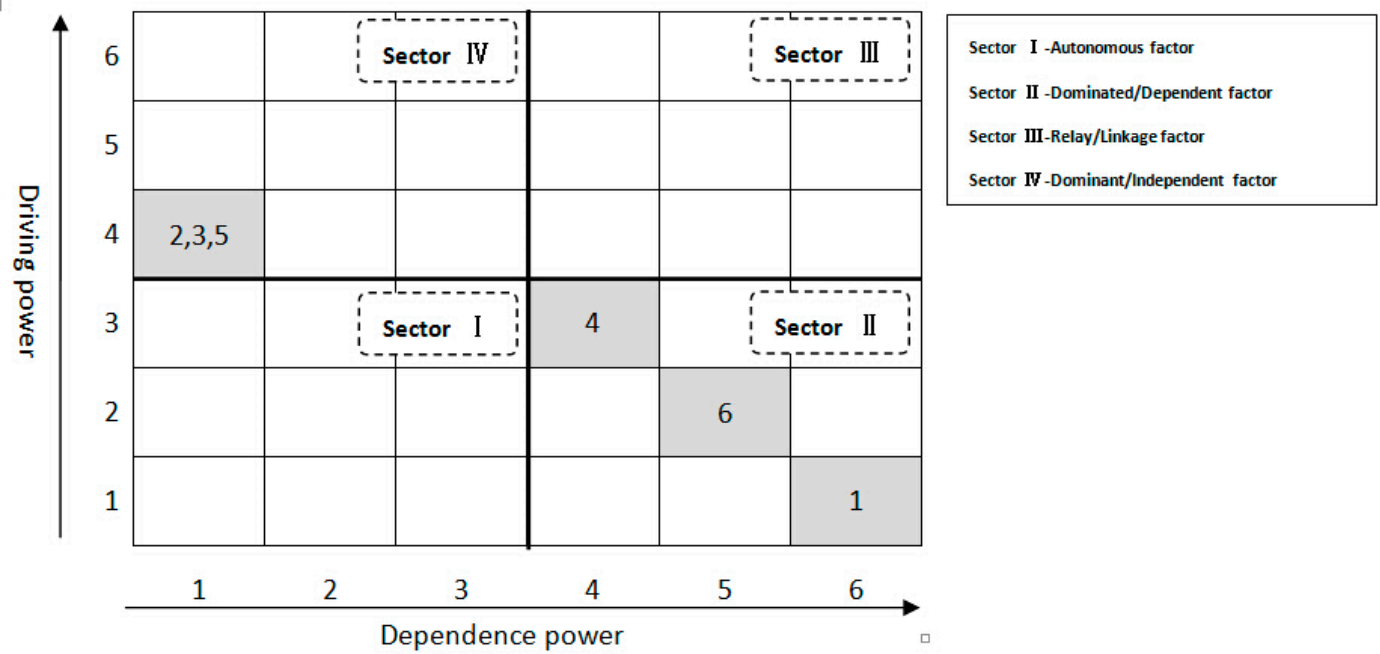

Figure 3. The diagram of MICMAC evaluation.

\subsection{Relationship and Influence Mechanism of the EI of Landless Peasants}

The ISM analysis of the influencing factors of the EI of landless peasants reveals that EE is a direct influencing factor at the surface layer; $\mathrm{IO}$ is an indirect influencing factor at the intermediate layer; and gender, AM, and LL are deeply rooted influencing factors.

(1) Interpretive structure of direct influencing factors at the surface layer

Among the direct influencing factors at the surface layer, the regression coefficient of the EE of landless peasants is 6.0569 , its statistical probability ( $p$-value) is 0.0000 , and it is significant at $1 \%$. Thus, the EE of landless peasants has a significantly positive effect on the EI of landless peasants, and the correlation of such an influence is great. The cultural level of landless peasants is generally low in China. They have simple access to knowledge and information. Their knowledge accumulation is extremely important outside farming experience. Thus, the entrepreneurship of landless peasants is special compared with other entrepreneurial groups. They need to rely on EE to help them interpret information from entrepreneurial opportunity identification and find hidden opportunities for entrepreneurship. Therefore, such a cognitive process of EE is a direct factor that triggers EI.

(2) Interpretive structure of indirect influencing factors at the intermediate layer

Among the indirect factors at the intermediate layer, the regression coefficient of $\mathrm{IO}$ is 1.4360 , its statistical probability ( $p$-value) is 0.0004 , and it is significant at $1 \%$. This finding indicates that the IO of landless peasants has a significant negative effect on the EI of landless peasants. IO plays an important role in initiating behavior intention. However, IO is negatively correlated with EI, which should be in conjunction with the actual object of study and local survey situation. According to Push-pull theory of EI, the types of entrepreneurship include survival-type entrepreneurship (involuntary entrepreneurship for survival) and opportunity-type entrepreneurship (voluntary entrepreneurship for higher achievement needs) [53-56]. Abbey and Dickson [57] believe that the EI of opportunity-type entrepreneurship is positively related to innovation orientation. The opportunity-type entrepreneurs clearly have more chances to choose. On the other hand, survival-type entrepreneurs have limited opportunities to choose for engaging in entrepreneurial activity. Therefore, there is a negative correlation between innovation orientation and the EI of survival-type entrepreneurship. This can also be confirmed by field surveys. Field surveys identified that, unlike general entrepreneurship, the entrepreneurship of landless peasants mostly serves the purpose of subsistence and follows suit without strong independent innovation capability. Thus, most of the landless peasants belong to survival-type entrepreneurs, who are affected by individual characteristics (e.g., education) and social 
circumstances (e.g., social security). In this situation, landless peasants seem to have no better choice than to engage in entrepreneurial activity under subsistence pressure. However, they have weak innovation orientation under high EIs. Therefore, IO is an indirect factor that triggers EI.

(3) Interpretive structure of deeply rooted influencing factors

Among the deeply rooted influencing factors, the regression coefficient of gender is 1.0800 , its statistical probability ( $p$-value) is 0.0541 , and it is significant at $10 \%$. This finding indicates that gender differences have a significant positive effect on the EI of landless peasants. The results prove that the EI of men is greater than that of women. The entrepreneurship of female landless peasants is significantly less active than that of male landless peasants, and some differences exist in their thoughts. Women aged over 50 choose to stay at home, take care of their children, and undertake intergenerational upbringing. Men behave differently. Even old male peasants do not want to stay at home and instead prefer to "look for a job" to improve the economic conditions and ease the financial burdens of their families. This finding is consistent with most research results. Gender as an individual characteristic, is one of the important factors affecting the EI. Shaver and Scott [58] found that personal traits (such as gender) were one of the important factors influencing the individual's EI by analyzing the differences between entrepreneurs and non-entrepreneurs from a psychological perspective. Generally, the performance of gender characteristic influencing an individual's EI is mainly gender bias. The main reasons are as follows: First, gender bias is reflected in the difference from the physiological characteristics to the social characteristics. Male and female are gradually strengthened and formed a gender role suitable for their own characteristics because of the socialization process. Therefore, they assume the different social responsibility, which led to their EI to show a strong gender differences [58]. Second, gender bias is reflected in the difference from the social characteristics to the characteristics of cultural value relationship. The core personality traits of entrepreneurs are characterized by adventure, innovation, achievement, autonomy, and internal control. In the context of social culture, these characteristics of male are stronger than female. Therefore, male are more willing to engage in high-risk jobs and choose their own business than female [59]. Third, gender bias is also reflected in the difference from the cultural value relationship to the unequal right relationship, which includes education level, self-efficacy, and entrepreneurial environment. For example, people in China's rural areas are generally influenced by traditional ideas (such as "patriarchal", and "men outside and women stay"). Thus, males have more educational opportunities than women, which leads to males' education level being generally higher than that of women [60]. Wilson et al. [61] argued that female tend to avoid entrepreneurship because of female entrepreneurs' self-perception was lower than that of men. The study of Langowitz and Minniti [62] found that female's entrepreneurial environment was not as good as men's because social support for women's entrepreneurship was less than that of men, which affected women's EI. The regression coefficient of AM is 0.7183 , its statistical probability ( $p$-value) is 0.0415 , and it is significant at $5 \%$. This finding indicates that AM has a significant positive effect on the EI of landless peasants. AM refers to the motivation that individuals pursue for important and valuable works and discipline according to high standards to achieve success. AM influences the EI of landless peasants. Landless peasants with AM tend to cherish EI. They are not afraid of difficulties and are not complacent with the status quo. They strive for excellence. Their risk tolerance is higher than that of average people. Therefore, focusing on the AM of landless peasants can guide them when conducting EI.

The regression coefficient of LL is 0.8508 , its statistical probability ( $p$-value) is 0.0109 , and it is significant at $5 \%$. This finding indicates that the land expropriation scenario has a significant positive effect on the EI of landless peasants. The role of triggering EI is influenced by gender and AM. It is also influenced by the land expropriation scenario, mainly because the land expropriation scenario causes changes in some elements of the individual resource level. Such changes easily influence the judgments of landless entrepreneurial individuals for entrepreneurial opportunities and markets. Most landless peasants in the survey consider that the land expropriation scenario 
has a great influence on entrepreneurship. Landless peasants who reside in city villages or urban fringes have easy access to information, market, policy, and other aspects because of their close distance to downtown areas and exposure to the radiation of urban economic development. They also have access to many entrepreneurship resources. Therefore, landless peasants in advantageous land expropriation locations are more likely to conduct entrepreneurship than those in disadvantageous land expropriation scenarios, such as remote rural areas and industrial parks.

Therefore, gender, AM, and LL are deeply rooted factors that trigger the EI of landless peasants.

\section{Discussion, Conclusions and Recommendations}

Peasants have experienced substantial land acquisition given the rapid industrial development and urbanization in China. Entrepreneurship is proposed as one of the most effective ways to settle landless peasants. EI is the first step to implement entrepreneurial behaviors [61] and affects landless peasants' employment and sustainable livelihood. However, the influencing factors of landless peasants' EI lack systematic investigations. Therefore, how to effectively promote entrepreneurship among landless peasants remains unknown. A theoretical analytical framework was established in this study following existing studies and a field survey of the EI of landless peasants. Five aspects and thirteen factors of the EI of landless peasants were selected. Logistic regression analysis was adopted to solicit the key influencing factors of the EI of landless peasants. ISM analysis was used to confirm the key factors influencing the EI of landless peasants. An interrelated and clearly hierarchical factor chain was established to clarify the inherent mechanism of the effects of the key influencing factors. Logistic regression analysis indicates that gender, AM, LL, and EE have a significant positive effect on the EI of landless peasants, among which LL and EE play dominant roles. IO has a significantly negative effect on the EI of landless peasants. ISM analysis indicates that EE is a direct influencing factor at the surface layer, which directly influences the enthusiasm of landless peasants for EI. IO is an indirect influencing factor at the intermediate layer, which is the external manifestation of deeply rooted factors. Gender, AM, and LL are deeply rooted influencing factors that trigger the occurrence of the EI of landless peasants.

According to the direct influencing factors at the surface layer, the local government should strengthen the accumulation of EE by constructing a training system of landless peasants. The training system should include formal training and informal training. Formal training is a method of mainstream recognition to increase the intention of landless peasants. The modes of formal training include compensatory education, guidance training, skills training, and planning training. In contrast, informal training on which landless peasants rely has not received the local government's attention. Informal training emphasizes the training mode of timeliness, integration and effectiveness based on modern human resource development, such as human capital investment, open education and lifelong education. The main modes of informal training are apprenticeship (one-to-one or one-to-many), partnership, and personal comprehension. The training system of landless peasants should be constructed with formal training and informal training to encourage landless peasants' entrepreneurship.

According to indirect influencing factors at the intermediate layer, the local government should encourage more innovative landless peasants to engage in entrepreneurial activities by enhancing the entrepreneurial atmosphere. The local government can promote typical stories and support the rural elite effect to enhance the entrepreneurial atmosphere [63], which will indirectly affect the EIs of landless peasants. Typical stories can cultivate the psychological awareness of landless peasants of starting businesses. The rural elite refers to the people who have abilities in entrepreneurship, marketing and technology in rural areas. They include the entrepreneurial elite, technical elite, and village cadres. They have made outstanding contributions to rural development and social progress. Many practices in rural China have proven that the leading path of typical stories and the rural elite is simple and clearly effective. According to the deeply rooted influencing factors, the local government should pay attention to gender differentiation guidance and overcome the impact of gender bias 
when formulating policies related to entrepreneurship. First, the entrepreneurship education system should be reformed and improved for the female landless peasants. In some developed countries, secondary and higher education institutions have tailor-made vocational education courses for female entrepreneurs, such as nurses, beauty, secretary and social welfare [64-69]. Meanwhile, the local government should emphasize related knowledge of education and training and policy tilt on the tertiary industry and micro-enterprises because the entrepreneurial projects for female landless peasants are concentrated in the tertiary industry and micro-enterprises. Second, the local government should encourage landless peasants' entrepreneurial motivation by establishing an individual entrepreneurship assessment mechanism (IEAM) and establishing entrepreneurial policy in different areas. First, considering the factors of gender and AM, the IEAM should be constructed according to the different psychological and physiological conditions of landless peasants. Landless peasants demonstrate differences in gender, age, and educational level. Therefore, the entrepreneurship evaluation mechanism of individual landless peasants should be established in a targeted and hierarchical manner. For issues such as whether landless peasants have an EI and whether they have a strong EI, local communities should conduct a psychological evaluation of landless peasants after land expropriation. Local communities should understand if these farmers want to become entrepreneurs and if they are suitable for entrepreneurship through professional psychological measurement, seminars, visits, and other means. The relevant evaluation results indicate that implementing shunt management for entrepreneurial and employed landless peasants and conducting entrepreneurship and employment guidance activities in a targeted manner are necessary. These procedures reduce the waste of resources and identify whether the local conditions of the entrepreneurship of landless peasants are ripe, rather than blindly launching entrepreneurship publicity and the training of landless peasants.

In addition, the distance from the expropriated LL to the downtown area and the land use type of expropriated land affect the entrepreneurial activities and intentions of landless peasants. Therefore, considering the different geographic conditions and implementing regional differentiation guidance policies are significant. For urban villages, urban fringes and other places with a relatively high level of economic development should be considered to improve the local entrepreneurship environment and expand the local entrepreneurship channels (i.e., the construction of entrepreneurship incubators and entrepreneurship service centers). For remote suburbs, industrial parks, other places with an ordinary level of economic development, and less developed areas, priority should be placed on the living security of landless peasants after land expropriation (i.e., improving satisfaction with compensation standards and implementing local employment and social security policies) to remove worries and doubts. For the outskirts, outer suburbs, and other places, the local investment environment should be improved, and unique development plans should be developed through investment attraction and other means.

The present study clarifies the interrelationships of influencing factors of landless peasants' EI through ISM. The findings can help the local government make effective entrepreneurship policies to enhance the EIs of landless peasants and promote entrepreneurship among landless peasants. Thus, the local government will effectively promote the sustainable livelihood development of the landless peasants. However, several shortcomings must be addressed. First, this study investigates only the south of the Yangtze River Delta. Other places in the Yangtze River Delta may also be considered as research areas. Future studies should also be conducted to study other relevant areas in China to provide a reference for effective entrepreneurship policies. Second, a large sample size needs to be further expanded. Future studies should enlarge the sample size to obtain more objective results. Third, other research on similar areas, such as the Pearl River Delta, should be conducted to understand spatial differences. The regional comparative analysis would be useful for obtaining a comprehensive understanding of landless peasants' entrepreneurship at the national or provincial level. 
Acknowledgments: This study is supported by MOE (Ministry of Education in China) Project of Humanities and Social Sciences "Study on the mechanism, simulation and policy support system of the underclass group's entrepreneurial behavior in the process of urbanization" (16YJC630030).

Author Contributions: Lu Han and Haijun Bao conceived and designed the experiments; Lu Han performed the experiments; Lu Han and Yi Peng analyzed the data; Lu Han contributed analysis tools; Lu Han wrote the paper. Lu Han, Haijun Bao and Yi Peng revised the paper.

Conflicts of Interest: The authors declare no conflict of interest.

\section{References}

1. Hui, E.C.M.; Bao, H. The logic behind conflicts in land acquisitions in contemporary China: A framework based upon game theory. Land Use Policy 2013, 30, 373-380. [CrossRef]

2. Lai, Y.; Peng, Y.; Li, B.; Lin, Y. Industrial land development in urban villages in China: A property rights perspective. Habitat Int. 2014, 41, 185-194. [CrossRef]

3. Lin, S.; Si, S. Factors affecting peasant entrepreneurs' intention in the Chinese context. Int. Entrep. Manag. J. 2014, 10, 803-825. [CrossRef]

4. Peng, Y.; Lai, Y.; Li, X.; Zhang, X. An alternative model for measuring the sustainability of urban regeneration: The way forward. J. Clean. Prod. 2015, 109, 76-83. [CrossRef]

5. Cheng, L.; Jiang, P.; Chen, W.; Li, M.; Wang, L.; Gong, Y.; Pian, Y.; Xia, N.; Duan, Y.; Huang, Q. Farmland protection policies and rapid urbanization in China: A case study for Changzhou City. Land Use Policy 2015, $48,552-566$.

6. Su, B.; Thierry, G.H.; Chen, Q.; Zhao, Q. The New Cooperative Medical Scheme and Self-Employment in Rural China. Sustainability 2017, 9, 304. [CrossRef]

7. Huang, X.; Huang, X.; He, Y.; Yang, X. Assessment of livelihood vulnerability of land-lost farmers in urban fringes: A case study of Xi'an, China. Habitat Int. 2017, 59, 1-9. [CrossRef]

8. Yao, J. Who is Jobless? A Comparison of Joblessness in Rural and Urban Areas in China. Asian Soc. Work Policy Rev. 2016, 11, 40-52. [CrossRef]

9. Wu, Y.; Peng, Y.; Zhang, X.; Skitmore, M.; Song, Y. Development priority zoning (DPZ)-led scenario simulation for regional land use change: The case of Suichang County, China. Habitat Int. 2012, 36, 268-277. [CrossRef]

10. Bao, H.; Cen, Y.; Peng, Y.; Yuan, D. Entrepreneurship and Intervention Strategies of Land-Lost Farmers in Urbanization Process of Zhejiang Province. Public Pers. Manag. 2016, 45, 37-57. [CrossRef]

11. Yang, X.; Day, J.; Han, S.S. Urban peripheries as growth and conflict spaces: The development of new towns in China. In Population Mobility, Urban Planning and Management in China; Springer: Geneva, Switzerland, 2015; pp. 95-112.

12. Baptista, R.; Leitão, J. Entrepreneurship, Human Capital, and Regional Development: Labour Networks, Knowledge Flows, and Industry Growth; Springer: New York, NY, USA, 2015.

13. Uhlenberg, P. International Handbook of Population Aging; Springer: Amsterdam, The Netherlands, 2009; Volume 107, pp. 233-234.

14. Bird, B. Implementing entrepreneurial ideas: The case for intention. Acad. Manag. Rev. 1988, 13, 442-453.

15. Hmieleski, K.M.; Corbett, A.C. Proclivity for improvisation as a predictor of entrepreneurial intentions. J. Small Bus. Manag. 2006, 44, 45-63. [CrossRef]

16. Barbosa, S.D.; Gerhardt, M.W.; Kickul, J.R. The role of cognitive style and risk preference on entrepreneurial self-efficacy and entrepreneurial intentions. J. Leadersh. Organ. Stud. 2007, 13, 86-104. [CrossRef]

17. Zhao, H.; Seibert, S.E.; Lumpkin, G.T. The relationship of personality to entrepreneurial intentions and performance: A meta-analytic review. J. Manag. 2010, 36, 381-404. [CrossRef]

18. Schildt, H.A.; Zahra, S.A.; Sillanpää, A. Scholarly communities in entrepreneurship research: A co-citation analysis. Entrep. Theory Pract. 2006, 30, 399-415. [CrossRef]

19. Shane, S. Prior knowledge and the discovery of entrepreneurial opportunities. Organ. Sci. 2000, 11, 448-469. [CrossRef]

20. Shane, S.A. A General Theory of Entrepreneurship: The Individual-Opportunity Nexus; Edward Elgar Publishing: Cheltenham, UK, 2004; Volume 12, pp. 353-374. 
21. Delmar, F.; Shane, S. Does experience matter? The effect of founding team experience on the survival and sales of newly founded ventures. Strateg. Organ. 2006, 4, 215-247. [CrossRef]

22. Davidsson, P.; Honig, B. The role of social and human capital among nascent entrepreneurs. J. Bus. Ventur. 2003, 18, 301-331. [CrossRef]

23. Baron, R.A.; Markman, G.D. Beyond social capital: The role of entrepreneurs' social competence in their financial success. J. Bus. Ventur. 2003, 18, 41-60. [CrossRef]

24. Lundstrom, A.; Stevenson, L.A. Entrepreneurship Policy: Theory and Practice; Springer: New York, NY, USA, 2005; Volume 1, pp. 557-559.

25. Jayeoba, F.I. Entrepreneurial intention and entrepreneurial abilities. IFE Psychol. 2015, 23, $219-229$.

26. Neave, G. Contrary imaginations: France, reform and the California master plan. In Clark Kerr's World of Higher Education Reaches the 21st Century; Springer: Amsterdam, The Netherlands, 2012; pp. 129-161.

27. Amjad, R. Employment Strategies and Labor Market Policies: Interlinkages with Macro and Sectoral Policies; Decent Employment Generation and Skills Development: Islamabad, Pakistan, 2006.

28. Kontos, M. Self-employment policies and migrants' entrepreneurship in Germany. Entrep. Reg. Dev. 2003, 15, 119-135. [CrossRef]

29. Bao, H.; Peng, Y. Effect of land expropriation on land-lost farmers' entrepreneurial action: A case study of Zhejiang Province. Habitat Int. 2016, 53, 342-349. [CrossRef]

30. De Los Ríos-Carmenado, I.; Ortuño, M.; Rivera, M. Private-Public Partnership as a Tool to Promote Entrepreneurship for Sustainable Development: WWP Torrearte Experience. Sustainability 2016, 8, 199. [CrossRef]

31. Pyysiäinen, J.; Anderson, A.; McElwee, G.; Vesala, K. Developing the entrepreneurial skills of farmers: Some myths explored. Int. J. Entrep. Behav. Res. 2006, 12, 21-39. [CrossRef]

32. De Haan, A. Social exclusion: Enriching the understanding of deprivation. Stud. Soc. Political Thought 2000, 2, 22-40.

33. Fuller-Love, N.; Midmore, P.; Thomas, D.; Henley, A. Entrepreneurship and rural economic development: A scenario analysis approach. Int. J. Entrep. Behav. Res. 2006, 12, 289-305. [CrossRef]

34. Herman, R.T.; Smith, R.L. Immigrant, Inc.: Why Immigrant Entrepreneurs Are Driving the New Economy (and How They Will Save the American Worker); John Wiley \& Sons: Hoboken, NJ, USA, 2009.

35. Zacher, H.F. Social Policy in the Federal Republic of Germany: The Constitution of the Social; Springer: Berlin/Heidelberg, Germany, 2013.

36. Achidi Ndofor, H.; Priem, R.L. Immigrant entrepreneurs, the ethnic enclave strategy, and venture performance. J. Manag. 2011, 37, 790-818. [CrossRef]

37. Hu, F. Return to Education for China's Return Migrant Entrepreneurs. World Dev. 2015, 72, $296-307$. [CrossRef]

38. Qian, M.J.; Huang, Y.S. Political institutions, entrenchments, and the sustainability of economic development-A lesson from rural finance. China Econ. Rev. 2016, 40, 152-178. [CrossRef]

39. Yu, J.; Zhou, J.X.; Wang, Y.G.; Xi, Y.M. Rural Entrepreneurship in an Emerging Economy: Reading Institutional Perspectives from Entrepreneur Stories. J. Small Bus. Manag. 2013, 51, 183-195. [CrossRef]

40. Ma, X.L.; Heerink, N.; van Ierland, E.; Shi, X.P. Land tenure insecurity and rural-urban migration in rural China. Pap. Reg. Sci. 2016, 95, 383-406. [CrossRef]

41. Lian, H.P.; Glendinning, A.; Yin, B. The Issue of 'Land-lost' Farmers in the People's Republic of China: Reasons for discontent, actions and claims to legitimacy. J. Contemp. China 2016, 25, 718-730. [CrossRef]

42. Ge, W.; Whitmore, G. Binary response and logistic regression in recent accounting research publications: A methodological note. Rev. Quant. Financ. Account. 2010, 34, 81-93. [CrossRef]

43. Jain, V.; Raj, T. A hybrid approach using ISM and modified TOPSIS for the evaluation of flexibility in FMS. Int. J. Ind. Syst. Eng. 2015, 19, 389-406. [CrossRef]

44. Jain, V.; Raj, T. Modeling and analysis of FMS performance variables by ISM, SEM and GTMA approach. Int. J. Prod. Econ. 2016, 171, 84-96. [CrossRef]

45. Attri, R.; Dev, N.; Sharma, V. Interpretive structural modelling (ISM) approach: An overview. Res. J. Manag. Sci. 2013, 2, 3-8.

46. Warfield, J.N. Developing interconnection matrices in structural modeling. IEEE Trans. Syst. Man Cybern. 1974, SMC-4, 81-87. [CrossRef] 
47. Rauner, F.; Maclean, R. Areas of TVET Research. In Handbook of Technical and Vocational Education and Training Research; Springer: Amsterdam, The Netherlands, 2008; pp. 157-610.

48. Krueger, N. The impact of prior entrepreneurial exposure on perceptions of new venture feasibility and desirability. Entrep. Theory Pract. 1993, 18, 5-21.

49. Hui, E.C.M.; Bao, H.J.; Zhang, X.L. The policy and praxis of compensation for land expropriations in China: An appraisal from the perspective of social exclusion. Land Use Policy 2013, 32, 309-316. [CrossRef]

50. Bao, H.; Deng, S.; Xu, S.; Peng, Y. Conspicuous consumption behavior of land-lost farmers: A perspective of social identity. Cities 2017, 66, 81-90. [CrossRef]

51. Ravi, V.; Shankar, R. Analysis of interactions among the barriers of reverse logistics. Technol. Forecast. Soc. Chang. 2005, 72, 1011-1029. [CrossRef]

52. Sharma, H.; Gupta, A.D.; Sushil. The objectives of waste management in India: A futures inquiry. Technol. Forecast. Soc. Chang. 1995, 48, 285-309. [CrossRef]

53. Gilad, B.; Levine, P. A behavioral model of entrepreneurial supply. J. Small Bus. Manag. 1986, 24, 45-53.

54. Olofsson, C.; Petersson, G.; Wahlbin, C. Opportunities and obstacles: A study of start-ups and their development. Front. Entrep. Res. 1986, 482-501.

55. Taormina, R.J.; Kin-Mei Lao, S. Measuring Chinese entrepreneurial motivation: Personality and environmental influences. Int. J. Entrep. Behav. Res. 2007, 13, 200-221. [CrossRef]

56. Berner, E.; Gomez, G.; Knorringa, P. 'Helping a Large Number of People Become a Little Less Poor': The Logic of Survival Entrepreneurs. Eur. J. Dev. Res. 2012, 24, 382-396. [CrossRef]

57. Abbey, A.; Dickson, J.W. R \& D work climate and innovation in semiconductors. Acad. Manag. J. 1983, 26, 362-368.

58. Shaver, K.G.; Scott, L.R. Person, process, choice: The psychology of new venture creation. Entrep. Theory Pract. 1991, 16, 23-45.

59. Caird, S. Testing enterprising tendency in occupational groups. Br. J. Manag. 1991, 2, 177-186. [CrossRef]

60. Riley, N.E. Gender, power, and population change. Popul. Bull. 1997, 52, 1-48.

61. Wilson, F.; Kickul, J.; Marlino, D. Gender, entrepreneurial self-efficacy, and entrepreneurial career intentions: Implications for entrepreneurship education. Entrep. Theory Pract. 2007, 31, 387-406. [CrossRef]

62. Langowitz, N.; Minniti, M. The entrepreneurial propensity of women. Entrep. Theory Pract. 2007, 31, $341-364$. [CrossRef]

63. Vázquez-Barquero, A.; Rodríguez-Cohard, J.C. Endogenous development and institutions: Challenges for local development initiatives. Environ. Plan. C Politics Space 2016, 34, 1135-1153. [CrossRef]

64. Liñán, F.; Rodríguez-Cohard, J.C. Assessing the stability of graduates' entrepreneurial intention and exploring its predictive capacity. Acad. Rev. Latinoam. Adm. 2015, 28, 77-98. [CrossRef]

65. Mason, C. Entrepreneurship education and research: Emerging trends and concerns. J. Glob. Entrep. 2011, 1, $13-25$.

66. O'Lawrence, H. Comparative new trends in career and technical education around the globe. Int. J. Vocat. Educ. Train. 2008, 16, 95-118.

67. Bamgbade, J.A.; Kamaruddeen, A.M.; Nawi, M.N.M.; Yusoff, R.Z.; Bin, R.A. Does government support matter? Influence of organizational culture on sustainable construction among Malaysian contractors. Int. J. Constr. Manag. 2017, 1-15. [CrossRef]

68. Peng, Y. A comparison of two approaches to develop concentrated rural settlements after the 5.12 Sichuan Earthquake in China. Habitat Int. 2015, 49, 230-242. [CrossRef]

69. Peng, Y.; Shen, Q.P.; Shen, L.Y.; Lu, C.; Yuan, Z. A generic decision model for developing concentrated rural settlement in post-disaster reconstruction: A China study. Nat. Hazards 2014, 71, 611-637. [CrossRef]

(C) 2017 by the authors. Licensee MDPI, Basel, Switzerland. This article is an open access article distributed under the terms and conditions of the Creative Commons Attribution (CC BY) license (http:/ / creativecommons.org/licenses/by/4.0/). 